\title{
The Unity of the Trajectory of Sustainable Development of the Mining Region and Ensuring its Environmental Safety
}

\author{
Oksana Sheveleva ${ }^{1, *}$, Ekaterina Slesarenko ${ }^{1}$, Natalia Kudrevatykh $^{1}$ and Tatiana Mamzina ${ }^{1}$ \\ ${ }^{1}$ T.F. Gorbachev Kuzbass State Technical University, 65000028 Vesennya st., Kemerovo, Russian \\ Federation
}

\begin{abstract}
Environmental safety can be considered as an integral and one of the most important parts of the concept of sustainable development of a coal-mining region, since the environmental risks occupy one of the leading places among the risks of backbone enterprises of such regions due to the particularities of the coal industry and its impact on the environment. In the article, environmental safety is assessed through indicators of the quality of atmospheric air and water, as well as investments in the restoration and protection of the environment; discrepancies were revealed between the amount of financial investments allocated to nature restoration measures and the results of the anthropogenic impact of coal mining enterprises on the biosphere; emphasis was placed on the need to improve the efficiency of funds allocated for environmental protection and rational use of natural resources. Considered priority areas of environmental activities implemented in the framework of the environmental policy of JSC SUEK-Kuzbass. The effectiveness of the system of environmental remediation measures developed by the Company, their adequate funding, makes it possible to place the Company among the industry leaders in environmental and social responsibility for its activities.
\end{abstract}

\section{Introduction}

Currently, the main factor in the sustainable development of mining regions is the change in the quality parameters of production processes based on the introduction of advanced, environmentally friendly technologies designed to minimize the harm done to the environment, man and the animal world.

The Kuznetsk coal basin, located in Kemerovo region, is one of the largest coal deposits in the world, so the problem of the environmental safety state is extremely important for Kuzbass. The region possesses significant mineral deposits and a variety of natural resources. Several industries are developed on the territory of Kemerovo region - coal mining, metallurgy, mechanical engineering and power engineering. However, Kuzbass specializes primarily in coal mining - there are more than 380 mines and open cuts in the region.

\footnotetext{
${ }^{*}$ Corresponding author: shob.fk@,kuzstu.ru
} 
The most important centers of the coal industry are the cities of Prokopyevsk, Mezhdurechensk, Belovo, Berezovsky, Kemerovo, Novokuznetsk, Leninsk-Kuznetsky, Novokuznetsky and Prokopevsky districts. There are more than two hundred mines and open cuts on the territory of the above cities and districts. There are two large coal basins Kuznetsk coal and Kansk-Achinsk lignite - in the region. The share of Kemerovo region accounts for mining more than $75 \%$ of coking coal.

\section{Research methodology}

The iinformation about the state of the natural environment (changes in weather, climate, the state of the animal and plant world around, etc.) has been actively used in human life since ancient times. Recently, changes in the environment are increasingly occurring under the influence of the human factor. The study of anthropogenic changes is the basis of environmental monitoring, which is an information system for analyzing and predicting the state of the environment and the management actions developed on this basis that are necessary to resolve issues in the field of environmental safety.

In Russia, considerable attention is paid to the environmental safety at the federal level, a number of legislative and regulatory acts have been developed, including: Federal Law "On Environmental Protection" No. 7-FZ dated January 10, 2002 (Chapter X. State Environmental Monitoring).

The regional level deserves special attention, since it is here where we can take into account the factors characteristic of the economies of specific territorial entities within the country [1-3], and therefore at this level specific problems can be considered and special programs for studying the environment state and the impact of anthropogenic factors on it can be developed.

\section{Results and discussion}

In order to identify the level of severity of environmental problems in Kuzbass, the comparative analysis of indicators of environmental monitoring of the quality of atmospheric air and water resources of Kemerovo region and the Siberian Federal District was conducted (Table 1). The indicators "Emissions of pollutants into the atmospheric air from stationary sources" and "Proportion of captured and treated atmospheric pollutants in the total amount of pollutants from stationary sources" are included in the State Program of the Russian Federation "Environmental Protection" for 2012-2020.

Table 1. Indicators of environmental monitoring of the quality of atmospheric air and water.

\begin{tabular}{|l|c|c|c|c|c|c|c|c|c|c|}
\hline \multirow{2}{*}{ Indicators } & \multicolumn{7}{|c|}{ Years } \\
\cline { 2 - 10 } & $\mathbf{2 0 1 0}$ & $\mathbf{2 0 1 1}$ & $\mathbf{2 0 1 2}$ & $\mathbf{2 0 1 3}$ & $\mathbf{2 0 1 4}$ & $\mathbf{2 0 1 5}$ & $\mathbf{2 0 1 6}$ & $\mathbf{2 0 1 7}$ \\
\hline \multicolumn{1}{|c|}{ 1. Emissions of pollutants into the air from stationary sources, kilotons } \\
\hline $\begin{array}{l}\text { Siberian Federal } \\
\text { District }\end{array}$ & 5868 & 5919 & 6017 & 5816 & 5570 & 5688 & 5605 & 5764 \\
\hline Kemerovo region & 1411 & 1390 & 1360 & 1356 & 1332 & 1344 & 1349 & 1488 \\
\hline $\begin{array}{l}\text { Share of } \\
\begin{array}{l}\text { Kemerovo region } \\
\text { in Siberian }\end{array} \\
\begin{array}{l}\text { Federal District, } \\
\text { \% }\end{array}\end{array}$ & 24.1 & 23.5 & 22.6 & 23.3 & 23.9 & 23.6 & 24.1 & 25.8 \\
\hline \multicolumn{7}{|c|}{ 2. Captured air pollutants from stationary sources, kilotons } \\
\hline $\begin{array}{l}\text { Siberian Federal } \\
\text { District }\end{array}$ & 21998 & 23420 & 20896 & 19459 & 19469 & 18497 & 17401 & 18012 \\
\hline Kemerovo region & 4823 & 6321 & 5334 & 4512 & 4636 & 4683 & 4234 & 4422 \\
\hline
\end{tabular}




\begin{tabular}{|c|c|c|c|c|c|c|c|c|}
\hline \multicolumn{9}{|c|}{$\begin{array}{l}\text { 3. The proportion of captured and treated air polluting substances in the total amount of } \\
\text { pollutants from stationary sources, } \%\end{array}$} \\
\hline $\begin{array}{l}\text { Siberian Federal } \\
\text { District }\end{array}$ & 78.9 & 79.8 & 77.6 & 77.0 & 77.8 & 76.5 & 75.6 & 75.8 \\
\hline Kemerovo region & 77.4 & 82.0 & 79.7 & 76.9 & 77.7 & 77.7 & 75.8 & 74.8 \\
\hline \multicolumn{9}{|c|}{ 4. Discharge of polluted wastewater to surface water bodies, million cubic meters } \\
\hline $\begin{array}{l}\text { Siberian Federal } \\
\text { District }\end{array}$ & 2218 & 2142 & 2077 & 1941 & 1750 & 1696 & 1654 & 1640 \\
\hline Kemerovo region & 700 & 661 & 572 & 598 & 478 & 462 & 444 & 433 \\
\hline $\begin{array}{l}\text { Share of } \\
\text { Kemerovo region } \\
\text { in Siberian } \\
\text { Federal District, } \\
\%\end{array}$ & 31.6 & 30.9 & 27.5 & 30.8 & 27.3 & 27.2 & 26.8 & 26.4 \\
\hline \multicolumn{9}{|c|}{ 5. The volume of recycling and successively used water, million cubic meters } \\
\hline $\begin{array}{l}\text { Siberian Federal } \\
\text { District }\end{array}$ & 15739 & 16093 & 17052 & 16288 & 15997 & 16504 & 15978 & $\begin{array}{c}1587 \\
0\end{array}$ \\
\hline Kemerovo region & 4524 & 4759 & 5114 & 5043 & 4766 & 4895 & 4891 & 4895 \\
\hline $\begin{array}{l}\text { Share of } \\
\text { Kemerovo region } \\
\text { in Siberian } \\
\text { Federal District, } \\
\%\end{array}$ & 28,7 & 29,6 & 30,0 & 30,1 & 29,8 & 29,7 & 30,6 & 30,8 \\
\hline
\end{tabular}

The amount of emissions of pollutants into the air from stationary sources in the Siberian Federal District in 2010-2017 varied from 5.5 to 6 thousand tons, and in the Kemerovo Region - from 1.3 to 1.5 thousand tons. Thus, the share of emissions of pollutants into the atmospheric air in Kuzbass accounted for $22.6-25.8 \%$, i.e. almost a quarter of all pollutant emissions in the district. Moreover, the highest concentration of emissions was noted in 2017 (1,488 thousand tons), which led to an increase in the share of Kuzbass in the overall structure of emissions of the Siberian Federal District to $25.8 \%$. According to this indicator, the Kemerovo region hold the second place (behind only the Krasnoyarsk Territory) among the 12 regions of the Siberian Federal District, which indicates the severity of this problem for our region. In 2017 compared to 2010, the amount of pollutant emissions into the atmospheric air in Kuzbass increased by 5.5\% (from 1,411 thousand tons to 1,488 thousand tons), while the similar indicator in the District decreased by $1.8 \%$. At the same time, the share of coal production in Kuzbass accounts for $61.5 \%$ of the total amount of pollutant emissions into the atmospheric air (915 thousand tons), i.e. the coal mining industry is the main air pollutant in the region.

According to the indicator "The proportion of captured and treated air polluting substances in the total amount of pollutants from stationary sources," the Kemerovo Region is in 7th place among 12 regions of the Siberian Federal District. The percentage of captured and treated atmospheric pollutants in the total amount of pollutants in Kuzbass is comparable to that in the District. In 2017, there is a slight lag in the indicator for the Kuzbass compared to the District data - by $1 \%$, which is not critical because the situation changes from year to year, with a slight change in the direction of increase and decrease.

However, the situation looks quite different if we consider it in terms of absolute indicators, namely: 25.2\% of non-treated air pollutants in 2017 in Kuzbass amount to 1,488 thousand tons of emissions per one region - Kemerovo region, while $24.2 \%$ of nondisposed substances in the District is 5764 thousand tons, which is 480 thousand tons per one region of the District (taking into account that there are 12 regions in the Siberian Federal District), i.e. emissions in Kuzbass are 3 times higher than the average in other regions of the Siberian Federal District. 
The situation of polluted wastewater discharge into surface water bodies is being improved in the both in the Siberian Federal Distrcit and Kuzbass. Thus, in the Siberian Federal District, discharges for 2010-2017 decreased by $26.1 \%$, and in the Kemerovo region - by $38.2 \%$. However, despite the rapid decline in discharges in the region compared to the District, the Kuzbass and in 2017 ranks second in this indicator among the 12 regions of the Siberian Federal District, and it accounts for more than a quarter of the total polluted wastewater discharge in the District.

Table 2. Composition and structure of investments in fixed assets, aimed at environmental protection and ration use of natural resources.

\begin{tabular}{|c|c|c|c|c|c|c|c|c|c|}
\hline \multirow{2}{*}{ Indicators } & \multicolumn{9}{|c|}{ Years } \\
\hline & 2010 & 2011 & 2012 & 2013 & 2014 & 2015 & 2016 & 2017 & 2018 \\
\hline $\begin{array}{l}\text { Investments } \\
\text { in fixed } \\
\text { assets, } \\
\text { including }\end{array}$ & 714.9 & 1161.6 & 1713.1 & 1404.4 & 2833.1 & 2058.1 & 1668.9 & 3150.1 & 2954.2 \\
\hline $\begin{array}{l}\text { 1) on } \\
\text { protection } \\
\text { and rational } \\
\text { use of water } \\
\text { resources }\end{array}$ & 251.2 & 556.0 & 1459.1 & 1143.2 & 2025.7 & 1107.0 & 1255.5 & 2651.7 & 1847.3 \\
\hline $\begin{array}{l}\text { - the same } \\
\text { as a } \\
\text { percentage } \\
\text { of } \\
\text { investments } \\
\text { in fixed } \\
\text { assets }\end{array}$ & 35.1 & 47.9 & 85.2 & 81.4 & 71.5 & 53.8 & 75.2 & 84.2 & 62.5 \\
\hline $\begin{array}{l}\text { 2) on } \\
\text { protection } \\
\text { of } \\
\text { atmospheric } \\
\text { air }\end{array}$ & 292.5 & 506.4 & 105.7 & 144.6 & 67.6 & 337.4 & 220.1 & 385.3 & 584.5 \\
\hline $\begin{array}{l}\text { - the same } \\
\text { as a } \\
\text { percentage } \\
\text { of } \\
\text { investments } \\
\text { in fixed } \\
\text { assets }\end{array}$ & 40.9 & 43.6 & 6.2 & 10.3 & 2.4 & 16.4 & 13.2 & 12.2 & 19.8 \\
\hline $\begin{array}{l}\text { 3) to other } \\
\text { activities } \\
\text { (including } \\
\text { protection } \\
\text { and rational } \\
\text { use of land) }\end{array}$ & 171.2 & 99.2 & 148.3 & 116.6 & 739.8 & 613.7 & 193.3 & 113.1 & 522.4 \\
\hline $\begin{array}{l}\text { - the same } \\
\text { as a } \\
\text { percentage } \\
\text { of } \\
\text { investments } \\
\text { in fixed } \\
\text { assets }\end{array}$ & 24.0 & 8.5 & 8.6 & 8.3 & 26.1 & 29.8 & 11.6 & 3.6 & 17.7 \\
\hline
\end{tabular}

Within 2010-2017, the amount of investment in fixed assets aimed at environmental protection and rational use of natural resources in the Kemerovo region increased by 4.1 
times. The largest share of investments throughout the analyzed period (except for 2010) is accounted for by investments in the protection and rational use of water resources (in 2017 it is $62.5 \%$ of the total investment in fixed assets). The amount of investments in this environmental protection area over the eight analyzed years increased by 1,596.1 million rubles, or 7.4 times.

Return on such investments was expressed:

- in reducing the polluted wastewater discharge into surface water bodies by $38 \%$ or 267 million cubic meters;

- in the growth of savings in fresh water intake through the use of recycling and reverse water supply systems, which reflects the indicator of the volume of recycling and successively used water - there is a rapid growth in the Kuzbass (an increase of $8.2 \%$ ) compared to the increase in this indicator for the SFD only $0.8 \%$ (Table 1 ).

Return on investments in fixed assets for air protection was less productive - with an increase in the amount of investments by 292 million rubles, or almost 2 times, emissions of pollutants into the air from stationary sources increased, and the proportion of captured and treated air pollutants decreased. It is quite possible to recognize such a situation as logical from the point of view of the formation of the structure of investments in fixed assets, since the share of investments in air protection in the total amount of investments decreased by $21.1 \%$.

When analyzing the ratio of investments (table 2) and commissioning of facilities for environmental protection and rational use of natural resources (table 3 ), there is no obvious correlation between these indicators. So, the amount of investments in 2010 being 251.2 million rubles; the capacities of the commissioned wastewater treatment facilities were only 0.7 thousand cubic meters per day, and a year later, with the amount of investments exceeding only 2.2 times, the capacities of the commissioned facilities were 220 times more!

Table 3. Dynamics of commissioning of facilities for environmental protection and rational use of natural resources.

\begin{tabular}{|l|l|l|l|l|l|l|l|l|c|}
\hline \multirow{2}{*}{ Indicators } & \multicolumn{2}{|c|}{ Years } \\
\cline { 2 - 9 } & $\mathbf{2 0 1 0}$ & $\mathbf{2 0 1 1}$ & $\mathbf{2 0 1 2}$ & $\mathbf{2 0 1 3}$ & $\mathbf{2 0 1 4}$ & $\mathbf{2 0 1 5}$ & $\mathbf{2 0 1 6}$ & $\mathbf{2 0 1 7}$ & $\begin{array}{c}\mathbf{2 0 1} \\
\mathbf{8}\end{array}$ \\
\hline $\begin{array}{l}\text { Wastewater } \\
\text { treatment facilities, } \\
\text { thousand cubic } \\
\text { meters per day }\end{array}$ & 0.7 & 154.5 & 34.8 & 110 & 69.9 & 124.4 & 22.9 & 94.0 & $\begin{array}{c}189 . \\
8\end{array}$ \\
\hline $\begin{array}{l}\text { Plants for trapping } \\
\text { and treatment of } \\
\text { harmful substances } \\
\text { from waste gases, } \\
\text { thousand cubic } \\
\text { meters per hour }\end{array}$ & 600 & 1036 & 471.7 & 322 & - & 75.7 & 27.6 & 16.0 & 30.0 \\
\hline
\end{tabular}

The situation of efficiency of investments in the protection of atmospheric air the looks even more ambiguous - the amount of investment is increasing annually, while reducing the commissioning of facilities for capture and treatment of harmful substances from waste gases. At the same time, according to statistics, the type of economic activity "Mining" is the main source of emissions of pollutants into the atmosphere. The emissions figures are comparable with two other activities - "polluting sources" ("Manufacturing industries" and "Providing electric energy, gas and steam"), but the emissions for these two types of activity even in total terms are 2 times lower. As for all other types of economic activity, the exceedance of emissions in mining is hundreds of times higher! In this regard, it is 
completely natural that the investment in environmental protection measures in mining should be maximal.

However, according to statistics, the efficiency of disposal of harmful substances in the mining industry of Kuzbass is quite low - the proportion of captured and treated harmful substances from all sources of pollution in mining ranges from $43 \%$ to $50 \%$ in $2013-2017$ years, i.e. more than half of the harmful substances remain in the atmospheric air, adversely affecting the quality of life of people, an increase in morbidity and mortality, and a decline in the birth rate.

Table 4. Dynamics of current (operational) environmental costs.

\begin{tabular}{|c|c|c|c|c|c|c|}
\hline \multirow[b]{2}{*}{ Indicators } & \multicolumn{6}{|c|}{ Years } \\
\hline & 2012 & 2013 & 2014 & 2015 & 2016 & 2017 \\
\hline $\begin{array}{l}\text { Total, mln. Rub., } \\
\text { including }\end{array}$ & 5708 & 7579 & 10224 & 6858 & 7250 & 9688 \\
\hline $\begin{array}{l}\text { 1. air protection and climate change } \\
\text { mitigation, mln. Rub. }\end{array}$ & 1764 & 2097 & 3240 & 1920 & 2114 & 3614 \\
\hline $\begin{array}{l}\text { - the same as a percentage of } \\
\text { current environmental costs }\end{array}$ & 30.9 & 27.7 & 31.7 & 28.0 & 29.2 & 37.3 \\
\hline 2. wastewater treatment, mln. Rub. & 2599 & 4129 & 5314 & 3543 & 4292 & 5051 \\
\hline $\begin{array}{l}\text { - the same as a percentage of } \\
\text { current environmental costs }\end{array}$ & 45.5 & 54.5 & 52.0 & 51.7 & 59.2 & 52.1 \\
\hline $\begin{array}{l}\text { 3. other activities in the field of } \\
\text { environmental protection, mln. Rub. }\end{array}$ & 1345 & 1353 & 1670 & 1395 & 844 & 1023 \\
\hline $\begin{array}{l}\text { - the same as a percentage of } \\
\text { current environmental costs }\end{array}$ & 23.6 & 17.8 & 16.3 & 20.3 & 11.6 & 10.6 \\
\hline
\end{tabular}

In 2012-2017, in Kuzbass, an increase in the current (operational) costs of environmental protection was by 3,980 million rubles or by $69.7 \%$, including rising costs for air protection and climate change mitigation, amounted to 1,850 million rubles (or 2 times), wastewater treatment - 2452 million rubles $(94.3 \%)$, waste management - 251 million rubles $(51.4 \%)$. The remaining costs decreased to a critical level, for example, over the past five years, the cost of ensuring the radiation safety of the environment decreased by 17 times, and in 2015-2017 the costs of research and development activities to reduce negative anthropogenic environmental impacts, and biodiversity conservation and protection of natural territories.

The largest share in the structure of current (operational) expenditures on environmental protection in Kemerovo region over the past five years was attributed to wastewater treatment costs. So, in 2017, the share of these costs amounted to $52 \%$ of the total amount.

Thus, for the regions with the predominant location of the coal mining industry (including Kuzbass), the following main environmental problems are characteristic:

- topsoil disturbance, as well as its contamination by waste generated by the operations of mines and open cuts;

- negative impact on water bodies as a result of discharges of pollutants into them, as well as washing off surface pollution from the territories of mines, open cuts and dumps;

- plant cover depletion due to open cut mining, often causing complete destruction of soil and vegetation;

- increasing emissions of pollutants into the air from stationary sources, and reducing the proportion of captured and treated air pollutants;

- exacerbation of the sanitary and epidemiological situation, causing a deterioration in the health of the population, an increase in morbidity and mortality. 
All these problems are often conditioned by the lack of incentives for the environmental activities of coal enterprises. It is more profitable for the economic entities to pay for the negative impact on the environment than to carry out reconstruction and modernization of production in order to reduce the harmful effects.

The experience of coal industry enterprises that are leaders in social accountability and corporate sustainability and implement a ramified and ambitious environmental policy, deserves special attention in this regard.

One of these companies that have been mining coal in Kuzbass since 2001 is JSC "SUEK". Coal is mined in 17 mines and 12 mines, which are located in seven regions of Russia. From 2005 to 2017, coal production increased by $39 \%$. The volume of "SUEK" coal reserves is 5.61 billion tons - according to this indicator, "SUEK" ranks fifth in the world. SUEK's strategy provides for sustainable long-term competitiveness based on an integrated chain of production, transportation and marketing of coal, and provides for strategically important areas, including a special emphasis on sustainable development, including investment in environmental, public and social projects to improve well-being of the regions in which it operates.

In the Kemerovo region, JSC "SUEK-Kuzbass" mines coal in 2 open cuts and 9 mines. In order to improve the quality of coal, it is processed in 4 concentration plants in the region. The activities of JSC "SUEK-Kuzbass" are related to various factors that have an impact on the environment (Table 5), and since exceeding the permissible levels of impact on natural resources is fraught with fees for pollution in excess of the established limits, administrative liability, or suspension of activities, then to reduce environmental risks an environmental policy has been developed in the enterprise to reduce the impact of these factors.

Table 5. Lines of environmental policy of JSC "SUEK-KUZBASS".

\begin{tabular}{|l|c|c|c|}
\hline $\begin{array}{c}\text { Factors } \\
\text { affecting the } \\
\text { environment }\end{array}$ & Types of monitoring & Monitored Indicators & $\begin{array}{c}\text { Priority areas of } \\
\text { environmental activities }\end{array}$ \\
\hline $\begin{array}{l}\text { air pollutant } \\
\text { emissions }\end{array}$ & $\begin{array}{c}\text { monitoring of air } \\
\text { pollutant emission } \\
\text { sources }\end{array}$ & $\begin{array}{c}\text { air quality of the } \\
\text { working area, } \\
\text { atmospheric air at the } \\
\text { industrial site and in } \\
\text { the sanitary protection } \\
\text { zone }\end{array}$ & $\begin{array}{c}\text { gradual reduction of } \\
\text { emissions of pollutants } \\
\text { (above all, greenhouse } \\
\text { gases and solids) into the } \\
\text { atmosphere }\end{array}$ \\
\hline $\begin{array}{l}\text { discharge of } \\
\text { pollutants into } \\
\text { surface water } \\
\text { bodies }\end{array}$ & $\begin{array}{c}\text { monitoring of surface } \\
\text { and ber bodies above } \\
\text { discharge point }\end{array}$ & $\begin{array}{c}\text { the quality of } \\
\text { wastewater discharged } \\
\text { from technological } \\
\text { facilities and entering } \\
\text { the treatment plant, } \\
\text { treated wastewater, } \\
\text { surface water }\end{array}$ & $\begin{array}{c}\text { discharges of polluted } \\
\text { wastewater into water } \\
\text { bodies }\end{array}$ \\
\hline $\begin{array}{l}\text { soil disturbance } \\
\text { in the process } \\
\text { of mining }\end{array}$ & $\begin{array}{c}\text { waste disposal sites } \\
\text { monitoring }\end{array}$ & waste disposal sites & $\begin{array}{c}\text { arrangement of waste } \\
\text { disposal sites to reduce } \\
\text { the man-made impact on } \\
\text { the environment }\end{array}$ \\
\hline
\end{tabular}

Following on the principles of the environmental policy, JSC "SUEK-Kuzbass" introduced an environmental management system certified in 2009 for compliance with the requirements of the international standard ISO 14001: 2004. Environmental indicators are monitored by accredited sanitary and hygienic and sanitary and industrial laboratories. The company has defined goals and objectives for meeting the standards for discharges and emissions of pollutants and mined-land reclamation; hazards were identified, environmental risks were estimated, measures aimed at minimizing these risks were developed, i.e. 
comprehensive and diverse work is underway to reduce the negative impact on the environment in the region.

However, despite fairly close attention to the issues of ensuring environmental safety at the federal level, the problem of the anthropogenic impact of industrial enterprises on the ecosystem, as well as improving the efficiency of the implemented environmental protection and recovery measures, remains one of the most pressing. Thus, a number of scientists $[4,5]$ recognize the threat of low social accountability and corporate sustainability as one of the most acute in addressing issues of improving environmental safety. The problem of accumulated waste from industrial enterprises, as well as their storage and disposal is widely investigated in the works of such authors as M.A. Gasanov, K.A. Kolotov [6], A.G. Koryakov, M.V. Kulikov [7], M. Kwiatkowski [8]. The relationship between environmental protection and investment in innovation processes is presented in the works of C. Barra, G. Bimonte, L. Senatore [9]. The influence of coal mining enterprises on the level and quality of life is described in the works of K. Mustafina [10], V.A. Ermolaev, A.V. Selyukov [11] and many other scientists.

At the same time, the successful global and regional experience in improving the environmental safety of industrialized regions $[12,13]$ provides a rich set of techniques and methods for their implementation.

\section{Conclusion}

Despite the presence of coal mining companies such as SUEK, a rather impressive number of mining companies use dirty technologies, without considering the most efficient methods for the conservation of mined-out rock masses and land reclamation. Rent-oriented behavior does not allow their owners to spend on these goals more than is required by law. In such conditions, the presence of even $20 \%$ of coal mining enterprises in the industrialized region, focused on reducing the anthropogenic impact of their activities, is unlikely to be able to fundamentally resolve the situation. The following systematic and comprehensive works in this direction are required:

1) increase of standard requirements for already operating coal mining enterprises in terms of investments in environmental innovations;

2) environmental certification of production of all enterprises of the coal industry taking into account the requirements of international standards;

3) development of a system of benefits for enterprises implementing measures to ensure the environmental safety;

4) use of higher tax rates for the production of environmentally hazardous products;

5) extended application of environmental insurance;

6) tightening the rules for coal mining enterprises when issuing mining licenses, in particular, reducing the corruption component in this aspect. There are frequent situations when regulatory authorities warn coal companies in advance about inspections, measurements of harmful emissions are carried out within a specified time, so violations, as a rule, are not detected;

7) changing the attitude of owners to environmental problems, promoting their social accountability and corporate sustainability;

8) introduction as a mandatory condition for the operation of coal mining enterprises of the gradual transfer of their production facilities to resource-saving, waste-free technological solutions, which allow minimizing the release of harmful substances into the environment. 


\section{References}

1. M. Cehlár, L. Mihok, Theoretical and Empirical Researches in Urban Management, 8:4, 60-72 (2013)

2. S. Zhironkin, D. Khloptsov, N. Skrylnikova, I. Petinenko, O. Zhironkina, E3S Web Conf., 41, 04010 (2018)

3. S. Zhironkin, S. Demchenko, G. Kayachev, M. Ryzhkova, O. Zhironkina, E3S Web Conf., 41, 04011 (2018)

4. O.V. Zonova, E.V. Nekhoda, Coal in the 21 st Century: Mining, Processing and Safety, 1, 125 (2016)

5. E. Ganebnykh, T. Burtseva, A. Petuhova, A. Mottaeva, E3S Web Conf., 91, 08035, (2019)

6. M.A. Gasanov, K.A. Kolotov, K.A. Demidenko, E.A. Podgornaya, O.V. Kadnikova, IOP Conf. Ser.: Earth Environ. Sci., 50:1, 012025 (2017)

7. A.G. Koryakov, M.V. Kulikov, Economics and Innovation Management, 4, 16-26 (2018) DOI: 10.26730/2587-5574-2018-4-16-26

8. M. Kwiatkowski, Archives of Waste Management and Environmental Protection, 12:4, 40 (2010)

9. C. Barra, G. Bimonte, L. Senatore, Innovation Processes and Environmental Safety (IEPA, Rome, 2018)

10. K. Mustafina, Alma Tourism, 5, 109 (2012)

11. V.A. Ermolaev, A.V. Selyukov, Journal of Mining and Geotechnical Engineering, 2(5), 42-55 (2019). DOI: 10.26730/2618-7434-2019-2-42-55

12. R. Chuturkova, A. Simeonova, J. Bekyarova, N. Ruseva, V. Yaneva, Journal of Environmental Protection and Ecology, 12:3, 805 (2011)

13. Nurongguli Tuoheti, Maimaitiaili Abulaiti, Zafar Ahmed, Namaitijiang Maimaiti, Journal of Politics and Law, 6:3, 160 (2013) 